\title{
Koping Keluarga Tidak Efektif Dengan Pendekatan Terapi Spesialis Keperawatan Jiwa
}

\author{
Jek Amidos Pardede \\ jekpardedemi@rocketmail.com
}

\section{BAB 1 \\ PENDAHULUAN}

\subsection{Latar Belakang}

Menurut Undang-Undang No.3 Tahun 1966,tentang Kesehatan jiwa, kesehatan jiwa adalah suatu kondisi yang memungkinkan perkembangan fisik,intelektual,dan emosional yang optimal dari seseorang dan perkembangan itu berjalan selaras dengan keadaan orang lain. Jadi dapat disimpulkan bahwa kesehatan jiwa adalah bagian integral dari kesehatan dan merupakan kondisi yang memungkinkan perkembangan fisik,dan sosial individu secara optimal,dan selaras dengan perkembangan kesehatan keluarga.

Kesehatan keluarga terdiri dari kesehatan fisik dan mental keluarga yang saling ketergantungan dimana kesehatan fisik dan mental tidak dapat dipisahkan karena saling mempengaruhi. Kesehatan mental akan mempengaruhi kesehatan fisik begitu juga sebaliknya. Kesehatan mental keluarga merupakan sebuah interaksi,kesehatan keluarga juga menunjukkan kepada keadaan,dimana terjadi proses internal atau dinamika,seperti hubungan interpersonal keluarga. Fokus terletak pada hubungan antara keluarga dan subsistem-subsistem lainnya,seperti subsistem orangtua atau keluarga dan para anggotanya. Jika dari anggota keluarga itu mengalami fisik atau mentalnya tidak sehat maka keluarga akan merasakan kecemasan yang mengakibatkan stress pada keluarga

Teori stress keluarga dari Hill (1949) dan McCubbin \& Petterson (1983) dalam Friedman,1998) mengemukakan bahwa stressor keluarga dapat menjadi suatu krisis,berhubungan dengan adanya sumber koping keluarga dan persepsi pada stressor tersebut. Sedangkan sumber koping dan persepsi dalam pengembangan strategi koping keluarga untuk mengatasi krisis/masalah. Bila keluarga memiliki sedikit sumber kopingnya baik secara individu maupun kolektif,maka proses koping tidak akan pernah dimulai dan krisis dapat terjadi ketika stress.

Sumber koping keluarga merupakan kekuatan individual dan kekuatan bersama pada saat menghadapi kejadian/stressor sebagai penyebab stress. Sumber koping tersebut 
antara lain: Jaminan ekonomi,kesehatan,pengetahuan sikap(intelegensi), kedekatan, semangat kerja sama,hubungan dengan yang lain serta dukungan sosial. Koping keluarga adalah proses aktif saat keluarga memamfaatkan sumber keluarga yang ada dan mengembangkan perilaku serta sumber baru yang akan memperkuat unit keluarga dan mengurangi dampak peristiwa hidup penuh stres.McCubbin,1979 dalam Friedman,1998). Dengan bergeser dari tingkat individu ke tingkat koping keluarga, koping menjadi semakin kompleks, karena kesulitan dalam mengkaji upaya koping keluarga, sebagian besar studi mengenai kelurga menjelaskan kombinasi individu dan respon koping keluarga yang dibuat oleh anggota keluarga dan keluarga. Respon atau perilaku koping keluarga adalah tindakan atau kognisi khusus yang dilakukan keluarga saat beradaptasi terhadap stres, sedangkan pola dan strategi koping adalah respon serupa yang berkelompok menjadi kumpulan yang homogen. Strategi koping keluarga dan individu terbentuk serta berubah sepanjang waktu,sebagai respon terhadap tuntutan atau stresor yang dialami (Friedman,1998). Teori tekanan keluarga menjadi dasar dalam mengurangi masalah melalui strategi koping yang efektif. Hal ini mencakup penanggulangan sebagai proses aktif untuk mengatur situasi perubahan tekanan/stressor yang meliputi pemamfaatan keberadaan sumber daya keluarga dan pengembangan perilaku baru sehingga akan memperkuat unit keluarga dalam mengurangi dampak peristiwa yang penuh tekanan.

\subsection{Tujuan}

1. Mampu memahami Psikodinamika dan psikopatologi koping keluarga tidak efektif

2. Mampu menetapkan terapi spesialis keperawatan yang sesuai dengan koping keluarga tidak efektif

3. Mampu menganalisa terapi yang dipih untuk menyelesaikan koping keluarga tidak efektif

4. Mampu mengusulkan terapi yang paling sesuai dengan masalah koping keluarga tidak efektif 


\section{BAB 2}

\section{TINJAUAN TEORITIS}

\subsection{Konsep Keluarga}

Keluarga adalah dua atau lebih individu yang hidup dalam satu rumah tangga karena adanya hubungan darah,perkawinan,atau adopsi. Mereka saling berinteraksi satu dengan yang lainnya,mempunyai peran masing-masing dan menciptakan serta mempertahankan satu budaya (Bailon \& Maglaya,1978 dalam Friedman,1998). Keluarga adalah dua atau lebih individu yang tergabung karena ikatan tertentu saling membagi pengalaman dan melakukan pendekatan emosional,serta mengidentifikasikan diri mereka sebagai bagian dari keluarga (Friedman,1998)

Lima fungsi keluarga menjadi saling berhubungan erat pada saat mengkaji dan melakukan intervensi dengan keluarga:

1. Fungsi efektif (fungsi mempertahankan kepribadian):

Memfasilitasi stabilisasi kepribadian orang dewasa,memenuhi kebutuhan psikologis anggota keluarga.

2. Fungsi sosial dan status sosial:

Memfasilitasi sosialisasi primer anak yang bertujuan menjadikan anak sebagai anggota masyarakat yang produktif,serta memberikan status pada anggota keluarga.

3. Fungsi reproduksi:

Untuk mempertahakan kontinuitas keluarga selama beberapa generasi dan untuk kelangsungan hidup masyarakat.

4. Fungsi ekonomi:

Menyediakan sumber ekonomi yang cukup dan alokasi efektifnya

5. Fungsi perawatan kesehatan:

Menyediakan kebutuhan fisik,makanan,pakaian,tempat tinggal,perawatan kesehatan (Friedman,1998)

Keluarga dapat memberikan perawatan kesehatan pada anggotanya yang sakit dengan membawa ke tempat-tempat fasilitas kesehatan untuk perawatan maupun rehabilitasi. Perawatan kesehatan ini dapat dilakukan oleh semua anggota keluarga secara bergiliran agar selain funsi ini dapat berjalan dengan baik tentu saja hal ini akan mengurangi beban bagi keluarga.

Selain dari fungsi perawatan kesehatan, ada faktor lain yang mempengaruhi kesehatan keluarga. Menurut Notoatmodjo (2003) faktor umur, jenis kelamin, kelas sosial, pekerjaan, jenis pekerjaan, penghasilan, status perkawinan, etnis atau budaya, besar keluarga, struktur keluarga dan paritas keluarga dapat mempengaruhi kesehatan dalam keluarga,baik kesehatan fisik maupun kesehatan mental. Friedman (1992, dalam Nies \& Mc.Ewen,2001) mengemukakan enam alasan pemberdayaan keluarga, yaitu: bila salah satu keluarga mngalami disfungsi maka berdampak pada anggota dan seluruh keluarga, potensi keluarga tergantung dari peran keluarga dari setiap aspek perawatan keluarga secar preventif dan 
rehabilitatif, potensi dapat ditingkatkan melalui perawatan dan mengurangi resiko pada lingkungan dan gaya hidup dan cara promosi kesehatan, self-care, pendidikan kesehatan, dan konseling keluarga, diskusi tentang penyakit atau faktor resiko untuk meningkatkan kemampuan untuk menyelesaikan masalah, funsgsi individu yang optimal hanya dapat tercapai bila mendapatkan bantuan dari sebagian besar keluarga, dan keluarga merupakan sistem pendukung utama.

Keluarga sebagai sistem sosial terdiri dari kumpulan dua orang atau lebih yang mempunyai peran sosial yang berbeda dengan ciri saling berhubungan dan tergantung antar individu,serta mempunyai komponen-komponen sistem.

Keluarga sebagai sistem mempunyai karakteristik dasar yang dapat dikelompokkan sebagai berikut:

1. Keluarga sebagai sistem terbuka

Suatu sistem yang mempunyai kesempatan dan mau menerima atau memperhatikan lingkungan/masyarakat sekitarnya.

2. Keluarga sebagai sistem tertutup

Suatu sistem yang kurang mempunyai kesempatan,kurang mau menerima/memberi perhatian kepada lingkungan/masyarakat sekitarnya.

Peran serta keluarga dalam perawatan klien gangguan jiwa :

1. Keluarga merupakan tempat dimana individu memulai hubungan interpersonal dengan lingkungan

2. Keluarga dipandang sebagai satu sistem sehingga gangguan yang terjadi pada salah satu anggota keluarga dapat mempengaruhi sistem,disfungsi dalam keluarga dapat sebagai penyebab gangguan

3. Berbagai pelayanan keperawatan jiwa bukan klien seumur hidup

4. Salah satu faktor penyebab gangguan jiwa adalah keluarga tidak tahu cara merawat klien dirumah

\subsection{Psikodinamika}

Koping adalah sebagai respon (kognitif,perilaku,atau persepsi) terhadap ketegangan hidup eksternal yang berfungsi untuk mencegah, menghindari,atau menngendalikan distress emosional (Pearlin \& Schooler,1978 dalam Friedman,1998). Koping merupakan sebuah istilah yang terbatas pada perilaku atau kognisi aktual yang ditampilkan seseorang bukan pada sumber yang mungkin mereka gunakan. Koping terdiri atas upanya pemecahan masalah yang dihadapi oleh individu dengan tuntutan yang sangat relevan dengangan kesejahteraannya,tetapi membebani sumber seseorang (Lazarus dkk,1974 dalam Friedman,1998). Koping Keluarga adalah sebagai proses aktif saat keluarga memamfaatkan sumber keluarga yang ada dan mengembangkan perilaku serta sumber baru yang akan memperkuat unit keluarga dan mengurangi dampak peristiwa hidup penuh stress (Mc Cubbin,1979 dalam Friedman,1998). Tuntutan terus-menerus memaksa keluarga beradaptasi 
dalam upanya bertahan,berlanjut,dan bertumbuh. Proses dan strategi koping keluarga sangat penting guna membuat hal ini mungkin.

Persepsi dan penanganan keluarga terhadap masalahnya melalui pemamfaatan berbagai sumber dan strategi koping amatlah penting bagi keberhasilan keluarga mengatasi tuntutan yang ada. Selain itu yang paling penting,proses dan strategi keluarga berfungsi sebagai proses atau mekanisme vital yang memfasilitasi fungsi keluarga. Tanpa keluarga yang efektif,fungsi efektif,sosialisasi,ekonomi,dan perawatan kesehatan tidak dapat dicapai secara adekuat. Oleh karena itu,proses dan strategi koping keluarga mengandung proses yang mendasar yang memungkinkan keluarga mengukuhkan fungsi keluarga keluarga yang diperlukan. Mengkaji sumber,strategi koping,dan proses keluarga memberikan landasan guna membantu keluarga dalam beradaptasi dan mencapai derajat kesejahteraan lebih tinggi.

Friedman(1998) membagi strategi koping keluarga menjadi koping keluarga internal dan koping keluarga eksternal. Koping keluarga internal atau intrafamilial adalah koping yang dilakukan dalam keluarga inti. Strategi koping internal terdiri dari:mengandalkan kelopok keluarga,penggunaan humor,memelihara ikatan keluarga,mengontrol arti dan makna dari masalah,pemecahan masalah secara bersama-sama,fleksibilitas peran,dan normalisasi. Koping internal berikutnya pengontrolan makna dari masalah dengan merumuskan kembali penilaian terhadap masalah (reframing) dan penilaian pasif terhadap masalah. Folkman,dkk (1986, dalam Friedman,1998) mengatakan bahwa keluarga yang menggunakan strategi koping ini cenderung melihat segi positif dan kejadian yang menimbulkan stres (refreming) dan mengabaikan aspek-aspek negatif (penilaian negatif) yang mengakibatkan stress dianggap kurang penting dalam kehidupan keluarga.

Strategi koping eksternal atau ekstrafamilial adalah koping yang dilakukan di luar keluarga inti. Kegiatan yang dilakukan pada koping ini meliputi: mencari informasi,memelihara hubungan aktif dengan komunitas,mencari dukungan sosial(menggunakana jaringan dukungan sosial informal,menggunakan sistem-sistem sosial informal,menggunakan kelompok-kelompok mandiri),dan mencari dukungan spritual. Strategi internal dan eksternal yang adekuat akan mengurangi atau menghilangkan beban, sebaliknya jika koping tidak adekuat maka akan meningkatkan atau menambah beban keluarga.

\subsection{Psikopatologi}

\subsubsection{Mekanisme stres dan adaptasi secara fisiologis}

Tanda peringatan pertama dari rasa takut,marah,frustasi,trauma,atau penyakit pada tubuh pertama diterima oleh syaraf sensoris yang disebut dengan organ sensoris seperti mata,telinga,lidah dan kulit yang terletak di bagian luar tubuh. Tanda-tanda peringatan ini diteruskan oleh syaraf ke hipotalamus dan korteks serebral. Hipotalamus terlibat karena organ ini mengontrol fungsi otomatis seperti pengaturan suhu tubuh,keseimbangan cairan dan sekresi hormon yang perannya sangat penting dalam memelihara homeostasis tubuh. Korteks serebral terlibat dalam fungsi ini untuk meningkatkan kesadaran seseorang terhadap stres yang dihadapinya agar individu dapat segera bereaksi mengatasi stres. 
Kedua pusat dalam otak ini harus terlibat untuk dapat mengadakan reaksi adaptasi terhadap stres baik secara fisiologis maupun psikologis. Kombinasi kedua reaksi ini merupakan usaha tubuh untuk melindungi diri terhadap stres dengan cara mengeluarkan tenaga cadangan yang diperlukan dalam beradaptasi. Dalam tahap ini,semua semua sistem organ dalam keadaan siaga dan siap untuk bertempur atau melarikan diri dari stres. Jantung bekerja lebih keras untuk meningkatkan curah jantung dan mengatur kadar oksigen serta gizi yang diperlukan untuk pengeluaran energi. Detak jantung bertambah cepat agar dapat meningkatkan jumlah oksigen yang diperlukan ,pembuluh darah meningkatkan kontraksi untuk membantu kerja peredran darah . otot-otot berkontraksi sehingga kaki,tangan dan punggung siap untuk bertindak jika perlu untuk melindungi tubuh terhadap ancaman. Produksi keringat meningkat,sebagai hasil peningkatan suhu tubuh yang dikeluarkan melalui mulut.

Hipotalamus merangsang sistem endokrin yang mengontrol kerja kelenjar hipofisis. Reaksi ini menyebabkan peningkatan produksi hormon yang mempengaruhi sebagian besar organ tubuh. Lobus posterior dari hipofisis mengeluarkan ADH(antidiuretic hormone) yang dibawa melalui aliran darah ke ginjal, yang merangsang ginjal menahan pengeluaran urine. Dengan cara ini volume darah meningkat untuk membantu sirkulasi oksigen dan zat-zat makanan lain untuk menghasilkan energi dan sebagai akibat kerja ini tekanan darah meningkat. Lobus posterior hipofisis juga menghasilkan beberapa macam hormon, salah satunya hormon tioksin yang merangsang tiroid untuk meningkatkan metabolisme tubuh supanya lebih banyak memproduksi energi yang langsung dapat dipakai. Hormon lain dalah genotropin yang dapat merangsang pankreas memproduksi glukogen yang merangsang hepar,otot,jaringan lemak untuk mengeluarkan energi yang tersimpan disana. Dengan cara ini memungkinkan produksi energi lebih banyak yang dipergunakan selama reaksi stres. Kelenjar hipofisis juga menyekresi hormon ACTH(adrenocorticotropic hormone) yang merangsang kelenjar adrenalin yang terletak di atas ginjal untuk menghasilkan hormon tambahan yang menahan air di ginjal dan meningkatkan volume darah, pengeluaran energi yang tersimpan dalam hepar,otot dan jaringan lemak. Kelenjar adrenalin juga mengeluarkan hormon tambahan yang disebut adrenalin. Adrenalin ini langsung bekerja ke berbagai organ tubuh,misalnya meningkatkan kerja jantung,melebarkan pupil,meningkatkan pengeluaran keringat dan menurunkan aktivitas gastrointestinal dan menyempitkan pembuluh darah maka efek psikologis adrenalin misalnya rasa takut dan rasa marah

Jika individu itu dapat mengatsi stres maka fungsi tubuh akan normal kembali tetapi bila gagal maka stres berlangsung terus sehingga persediaan tenaga dalam tubuh kan habis dan individu tersbut menjadi kepayahan. Seorang individu sering mengalami stres,sehingga terdapat perubahan fisiologis dalam jangka waktu lama maka akan terjadi keruskan yang menetap dalam tubuh.

\subsubsection{Pencetus Stres Sebagai Transaksi Antara Individu Dan Lingkungan}

Dalam hal ini defenisi stres menekankan pada hubungan antara individu dan lingkungan. Karakteristik pribadi yang sama alaminya dengan lingkungan perlu dipertimbangkan 
(Lazarus \& Folkman,1984 dalam Friedman,1998). Dengan kata lain untuk memprediksi stres psikologis sebagai suatu reaksi,karakteristik orang tersebut dalam berkaitan dengan lingkungan juga harus dipertimbangkan. Stres sebagai proses yang meliputi stresor dan strain dengan menambahkan dimensi hubungan antara individu dengan lingkungannya. Interaksi antara manusia dengan lingkungan yang saling mempengaruhi disebut sebagai hubungan traksasional. Stres bukan hanya suatu stimulus atau sebuah respon saja,tetapi juga suatu proses ketika seseorang adalah perantara (agent) yang aktif yang dapat mempengaruhi stresor melalui strategi perilaku,kognitif dan emosional.

Individu akan memberikan reaksi stres yang berbeda pada stresor yang sama. Sebagai contoh: bila mengamati perilaku orang di jalur lalu-lintas,orang-orang yang terjebak dijalur lalu- lintas dan terlambat datang dipertemuan penting,terus menerus akan melihat jam tangannyaa,sementara orang lain terlihat santai saja sambil menikmati musik. Dalam hal ini jelas terlihat bahwa terdapat perbedaan dalam mengartikan bahwa timbulnya kesadaran stres merupakan proses yang kompleks dan dinamis.

Peristiwa yang mencetuskan stres yaitu timbulnya suatu rangsangan dari lingkungan eksternal dan internal yang dirasakan oleh individu melalui sikap tertentu. Hal ini yang menentukan apakah suatu hubungan dengan seseorang atau lingkungan tertentu menimbulkan stres bergantung pada penilaian kognitif individu tentang situasi. Penilaian kognitif (cognitive appraisal) adalah suatu evaluasi individu terhadap kepentingan pribadinya pada peristiwa tersebut.

\subsubsection{Proses Terjadinya Koping Keluarga Tidak Efektik}

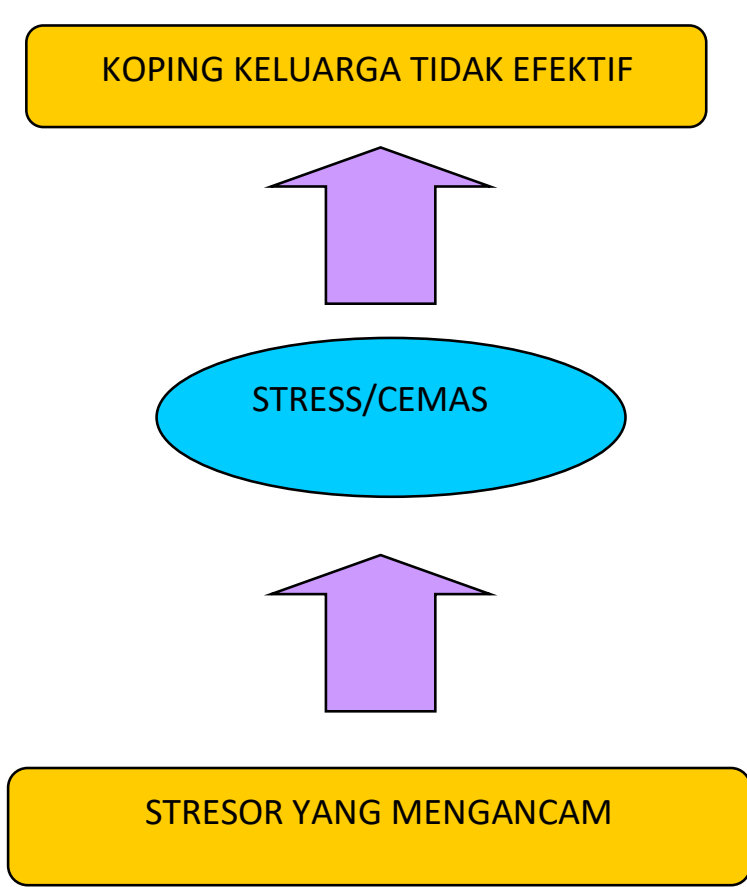

Pada awal mengalami stress, koping yang terlebih dahulu dilakukan adalah koping yang bersumber dari anggota keluarga itu sendiri. Burgess (1979,dalam Friedman,1998) mengatakan koping mengandalkan kelompok keluarga membutuhkan displin anggota keluarga karena didalamnya akan ada pembagian tugas yang harus dipikul oleh setiap 
anggota keluarga.contoh koping adalah membuat struktur lebih yang besar,meningkatkan kontrol dalam keluarga dan memodifikasi proses pengambilan keputusan

Dengan adanya masalah dari salah satu anggota keluarga,contohnya; mengalami penyakit kronis, penyakit yang membuat keluarga malu atau penyakit yang susah disembuhkan seperti: gangguan jiwa, penyakit stroke, HIV AIDS,dll. Dengan keadaan ini keluarga akan mengalami stress karena anggota keluarga yang mengalami masalah itu sudah menjadi stressor bagi keluarga dan akan menjadi stressor keluarga yang berkepanjangan sehingga koping keluarga mejadi tidak efektif.

Koping keluarga tidak efektif adalah suatu keadaan keluarga yang menunjukkan resiko tinggi perilaku dekstruktif dalam berespon terhadap ketidakmampuan untuk mengatasi stresor internal atau eksternal karena ketidakmampuan (fisik,psikologis,dan kognitif) yang dimiliki (Keliat dkk,2013). Koping keluarga tidak efektif adalah Perilaku orang terdekat bagi klien (anggota keluarga atau orang terdekat lainnya) yang membuat ketidakmampuan kapasitas mereka dan kapasitas klien untuk secara efektif melaksanakan tugas yang esensial,baik untuk adaptasi klien terhadap masalah kesehatan (Nanda,2005)

\subsubsection{Tanda dan Gejala Koping Keluarga tidak efektif}

Data yang dapat ditemukan didalam keluarga meliputi ketegangan dalam keluarga,menurunnya toleransi satu sama lain,permusuhan dalam keluarga,perasaan malu dan bersalah,perasaan tidak berdaya,agitasi,mengingkari masalah, harga diri rendah dan penolakan.

Penyebab gangguan ini adalah :

1. Orang yang penting atau berpengaruh dalam keluarga tidak mampu mengekspresikan perasaan seperti memendam rasa bersalah,kecemasan,permusuhan,keputusasaan.

2. Pola pengambilan keputusan keluarga yang sewenang-wenang(otoriter).

3. Hubungan antar anggota keluarga yang penuh dengan keragu-raguan. 


\subsection{Terapi Spesialis Keperawatan}

\subsubsection{Terapi Kelompok}

Terapi kelompok adalah psikoterapi yang dilakukan sekelompok klien bersama-sama dengan jalan berdiskusi satu sama lain dipimpin oleh seorang terapis atau petugas kesehatan jiwa yang terlatih (Direktorat Kesehatan Jiwa)

Terapi kelompok adalah terapi psikologi yang dilakukan secarakelompok untuk memberikan stimulasi bagi pasien dengan gangguaninterpersonal (Yosep, 2008).

\section{Terapi Supportif}

Supportif group adalah terapi yang berfokus kepada hubungan kelompok interaksi, antara anggota kelompok, dan juga pertimbangan terhadap issue yang dipilih, juga mencegah terjadinya krisis dimasa depan dengan mengajarkan peserta cara yang efektif untuk mengatasi stress emosional yang timbul dari krisis situasional atau krisis perkembangan(Townsen, 2008. Terapi suportif adalah model psikoterapi yang banyak digunakan dirumah sakit atau komunitas yang didasarkan kepada terapi berbasis mental dan banyak menggunakan teori psikodinamik tentang bagaimana cara merubah orang lain (Stuart \& Laraia, 2005)

Tujuan dari supportif group adalah untuk memberikan support terhadap kelompok sehingga mampu menyelesaikan krisis yang dihadapinya dengan cara membangun hubungan yang bersifat suportif antara klien-terapis, fokus untuk pemulihan, aksi sosial termasuk kebijakan organisasi. Tujuan utama adalah menyelesaikan permasalahan dengan segera, meningkatkan ketrampilan koping kelompok, meningkatkan kemampuan kelompok menggunakan sumber kopingnya, meningkatkan otonomi kelompok dalam keputusan tentang program pengobatan, meningkatkan kemampuan keluarga mencapai kemandirian seoptimal mungkin, serta meningkatkan kemampuan mengurangi distress subyektif dan respons koping yang maladaptif.

Dalam terapi kelompok ini individu saling berinteraksi antara satu dengan yang lain. Adanya interupsi, keheningan, penilaian, ketengangan adalah ciri dari proses kelompok (Clark, 1994 dalam Stuart, \& Laraia, 2005).

Menurut Lawrence Roland (1989) psikoterapi supportif digambarkan sebagai berikut antara lain: 
1. Dalam terapi suportif , terapis harus membina hubungan yang baik dengan klien.

2. Meningkatkan kekuatan klien, ketrampilan koping dan kemampuan untuk menggunakan sumber koping

3. Mengurangi distress klien dan respon koping maladaptif

4. Membantu klien mencapai sehat jiwa dan juga fisik

5. Meningkatkan otonomi klien dalam pengambilan keputusan terhadap pengobatan

Prinsip terapi suportif antara lain:

1. Membantu pasien mengatasi permasalahan

2. Keluarga dan sistem pendukung sosial ikut terlibat

3. Fokus kepada kehadiran

4. Menurunkan kecemasan melalui langkah-langkah supportif dan pengobatan jika diperlukan.

5. Klarifikasi dan penyelesaian masalah menggunakan pendekatan nasehat, konfrontasi suportif, pengaturan batasan, pendidikan, dan perubahan lingkungan.

6. Membantu pasien untuk menghindari krisis masa depan, dan pertolongan pertama ketika mengalami stress

Peran pasien dan terapis suportif

Menurut Stuart dan Laraia (2005) dalam terapi suportif :

1. Terapis bermain secara aktif dan berperan langsung membantu klien mengembangkan fungsi sosial dan ketrampilan koping.

2. Setting terapi suportif ini memungkinkan level dari yang rendah sampai yang tertinggi dari aktivitas klien dan terapis.

3. Komunikasi harus dua arah antara klien dan terapis dan berkolaborasi dengan terapis yang lain sebagai pendorong.

4. Terapis membangun hubungan terapeutik dengan pasien. Ekspresi empati, fokus, dan tidak menghakimi klien dalah hal yang penting yang harus dimiliki oleh terapis.

5. Terapis mendukung klien berusaha terhadap kesehatan yang adaptif, menghargai klien sebagai individu yang unik, meningkatkan kualitas hidup klien. Terapis menghargai klien sebagai partner dalam program terapi dan meningkatkan autonomi klien dalam membuat keputusan terhadap program terapi dan dalam hidupnya. 
Karakteristik Terapi Suportif

1. Kelompok kecil dan berjumlah 10-12 orang

2. Anggota homogen

3. Anggota berpartisipasi penuh dan mempunyai otonomi

4. Kepemimpinan secara kolektif (bersama-sama)

5. Keanggotaan sukarela dan tidak terlibat dalam kegiatan politik

6. Anggota saling membantu satu sama lain dan dapat melakukan pertemuan di luar sesi.

Aturan dalam supportif group adalah sebagai berikut :

1. Harus Kooperatif,

2. Menjaga keamanan dan keselamatan kelompok

3. Mengekspresikan perasaan dan keinginan berbagi pengalaman

4. Penggunaan waktu efektif dan efisien.

5. Menjaga kerahasiaan

6. Komitmen untuk berubah

7. Mempunyai rasa memiliki, berkontribusi,dapat menerima satu sama lain, mendengarkan, saling ketergantungan, mempunyai kebebasan, loyalitas, dan mempunyai kekuatan.

\subsubsection{Terapi Keluarga}

\section{Teori yang mendasari terapi keluarga}

Teori yang relevan dengan Family Therapiy, yang dikembangkan beberapi ahli dengan menggunakan pendekatan sistem.

1. Alfred Adler

Masalah-masalah yang terjadi pada salah seorang dalam keluarga, berlaku secara umum terhadap anggota lainnya dalam komunitas.

2. Murray Bowen

Keluarga merupakan faktor utama ketika dianalisis dari perspektif tiga generasi karena dapat melihat pola hubungan interpersonal anggota keluarga antar generasi. Kontribusi utamanya meliputi konsep inti diferensiasi diri dan triagulasi.

3. Virginia satir 
Terapi keluarga conjoint, sebuah model proses validasi manusia (sebuah pendekatan eksperimental) yang menekankan pada komunikasi dan pengalaman emosi.

4. Carl whitaker,

Pencipta terapi keluarga pengalaman-simbolis (symbolic-experiential family therapy), sebuah pendekatan intuitif untuk membantu interaksi terbuka dalam keluarga.

5. Salvador Minuchin

Berfokus kepada struktur atau organisasi keluarga, terapis membantu keluarga memodifikasi pola stereotype dan meredefinisikan hubungan di antara anggota keluarga.

6. Jay Haley

Strategic family therapy adalah sebuah pendekatan yang berfokus pada memecahkan masalah sekarang; memahami apa yang tidak dibutuhkan atau tidak diajukan.

7. Cloe Madanes

pendekatan terapi yang singkat dan berorientasi pada solusi.

menekankan pada kepedulian dan aspek emosional dari pola keluarga.

\section{Pengertian Terapi Keluarga}

Terapi keluarga adalah suatu cara untuk menata kembali masalah hubungan antar manusia (Stuart \& Laraia,2005)

Terapi keluarga adalah salah satu jenis terapi modalitas yang berfokus pada pengobatan seluruh anggota keluarga sebagai unit dan bentuk intervensi yang diberikan adalah membantu keluarga untuk mengidentifikasi dan mengubah masalah yang maladaptif, menyalahkan diri sendri, dan hubungan pola yang berulang (Goldenberg \& Goldenberg dalam Townsend, 2005).

\section{Tujuan Terapi Keluarga}

Tujuan terapi keluarga:

1. Menurunkan konflik keluarga

2. Meningkatakan kesadaran keluarga terhadap kebutuhan masing-masing anggota keluarga

3. Meningkatkan kemampuan penganan terhadap kritis 
4. Mengembangkan hubungan peran yang sesuai

5. Membantu keluarga menghadapi tekanan dari dalam maupun dari luar anggota keluarga

6. Meningkatkan kesehatan jiwa keluarga sesuai dengan tingkat perkembangan anggota keluarga

\section{Mamfaat Terapi Keluarga}

Klien

1. Mempercepat proses penyembuhan

2. Memperbaiki hubungan interpersonal

3. Menurunkan angka kekambuhan

Keluarga

1. Memperbaiki fungsi dan struktur keluarga

2. Keluarga mampu meningkatkan pengertian terhadap klien sehingga lebih dapat menerima,toleran dan menghargai klien sebagai manusia

3. Keluarga kesehatan jiwa keluarga sesuai dengan tingkat perkembangan anggota keluarga

\section{Indikasi Terapi Keluarga}

1. Komflik perkawinan,sibling konflik,dan konflik beberapa generasi

2. Konflik orang tua dan anak

3. Proses transisi

\section{Peran keluarga dalam Terapi}

Peran kelurga dalam terapi adalah:

1. Membuat suatu keadaan dimana anggota keluarga dapat melihat bahaya terhadap diri klien dan aktifitasnya

2. Tidak merasa takut dan mampu bersikap terbuka

3. Membantu anggota bagaimana memandang orang blain

4. Tempat bertanya serta pemberi informasi yang mudah dipahami klien

5. Membangun self-esteem

6. Menurunkan ancaman dengan latar belakang aturan untuk interaksi

7. Menurunkan ancaman dengan struktur pembahasan yang sistematis

8. Pendidikan ulang anggota untuk bertanggung jawab

\section{Harapan Terapi Keluarga}

1. Memberikan stimulasi dalam perkembangan anak

2. Menumbuhkan hubungan interpersonal

3. Mengerti tentang kesehatan jiwa dan gangguan kesehatan jiwa

4. Mengetahui penyebab gangguan jiwa 
5. Mengetahui ciri-ciri gangguan jiwa

6. Mengetahui fungsi dan tugas keluarga

7. Upanya pencegahan gangguan jiwa oleh keluarga

8. Upanya perawatan klien gangguan jiwa di RSU,Puskesmas Sumber: (Stuard \& Keliat.B)

\section{Terapi yang akan dibahas dalam makalah ini adalah Terapi Psikoedukasi Keluarga dan Terapi Triangle}

\section{Terapi Psikoedukasi Keluarga (Family Psychoeducation)}

Menurut Carson (2000), Psikoedukasi merupakan alat terapi keluarga yang makin populer sebagai suatu strategi untuk menurunkan faktor-faktor resiko yang berhubungan dengan perkembangan gejala-gejala perilaku. Jadi pada prinsipnya psikoedukasi dapat membantu anggota keluarga dalam meningkatkan pengetahuan tentang penyakit melalui pemberian informasi dan edukasi yang dapat mendukung pengobatan dan rehabilitasi pasien dan meningkatkan dukungan bagi anggota keluarga itu sendiri.

Psikoedukasi keluarga adalah salah bentuk terapi perawatan kesehatan jiwa keluarga dengan cara pemberian informasi dan edukasi melalui komunikasi terapetik. Program psikoedukasi merupakan pendekatan yang bersifat edukasi dan pragmatis (Stuart \& Laraia,2005) Psikoedukasi dapat dilakukan pada keluarga dengan gangguan seperti, skizoprenia,depresi mayor ,dan gangguan bipolar. Psikoedukasi juga dapat dilakukan pada keluarga yang memiliki masalah psikososial dan gangguan jiwa (Stuart \& Laraia,2005)

Tujuan utama dari terapi psikoedukasi keluarga adalah saling bertukar informasi tentang perawatan kesehatan mental akibat penyakit fisik yang dialami ,membantu anggota keluarga mengerti tentang penyakit anggota keluarganya seperti gejala,pengobatan yang dibutuhkan untuk menurunkan gejala dan lainnya (Vacarolis dkk,2006)

Indikasi psikoedukasi keluarga

1. Keluarga dengan masalah psikososial dan gangguan jiwa

2. Keluarga yang membutuhkan latihan ketrampilan komunikasi atau latihan menjadi orang tua yang efektif

3. Keluarga yang mengalami stres dan krisis

4. Keluarga yang membutuhkan pembelajaran tentang mental,keluarga yang mempunyai anggota keluarga yang sakit mental atau keluarga yang ingin mempertahankan kesehatan mentalnya dengan latihan ketrampilan

5. Keluarga yang membutuhkan pendidikan dan dukungan dalam upanya pencegahan timbulnya masalah mental keluarga

Proses Pelaksanaan

Adapun proses kerja untuk melakukan psikoedukasi pada keluarga adalah :

1. Persiapan 
a. Identifikasi dan seleksi keluarga (caregiver) yang membutuhkan pikosoedukasi sesuai indikasi dan kriteria yang telah ditetapkan

b. Menjelaskan tujuan dilakukan psikoedukasi keluarga

c. Membuat kontrak waktu, bahwa terapi akan dilaksanakan dalam beberapa kali pertemuan dan anggota keluarga (caregiver) yang mengikuti keseluruhan pertemuan adalah orang yang sama yang tinggal serumah dengan klien

2. Pelaksanaan

Berdasarkan tujuan yang akan dicapai, kelompok menganalisa pencapaian terapi dapat dilakukan pada 5 sesi :

Sesi 1 : Pengkajian maslah yang dialami

Sesi 2 : Cara perawatan klien gangguan jiwa

Sesi 3 : Manajemen stres keluarga

Sesi 4 : Manajemen beban keluarga

Sesi 5 : Pemberdayaan komunitas membantu keluarga

\section{Terapi Triangle (Triangle Therapy)}

Triangle adalah suatu unit sosial yang fundamental,dan triangulasi (keterlibatan pihak ketiga) yang merupakan suatu proses sosial yang bisa terjadi dimana saja. Terapi keluarga triangle merupakan salah satu terapi yang dapat mempengaruhi atau memperbaiki respon koping keluarga dalam pengambilan keputusan untuk menyelesaikan masalah yang dirasakan oleh keluarga (Shives,2005)

\section{Tujuan terapi triangle}

Terapi triangle ini dilakukan dengan tujuan untuk membantu pasangan dan individu mengantisipasi berbagai cara dalam menyelesaikan masalah-masalah yang timbul (Kazak,Simms \& Rourke,2002)

Menurut Perez (1979) Tujuan dari terapia Triangle ini adalah :

1. Untuk membantu keluarga meningkatkan pengetahuan

2. Menghentikan pengulangan hubungan keluarga yang menimbulkan masalah

3. Membantu individu,pasangan dalam hubungan keluarga

\section{Manfaat Terapi Triangle}

Menurut Kazak,simms,\& Rourke (2002), Mamfaat dari terapi triangle adalah :

1. Orientasi berfokus pada keluargaa bukan pada individu

2. Fokus pada pemahaman keluarga terhadap struktur keluarga,peran,fungsi,sosial dan budaya yang akan mempengaruhi stabilitas hubungan keluarga

3. Menjelaskan timbal balik hubungan keluarga sebagai tolak ukur keberhasilan

4. Membantu keluarga yang mempunyai masalah 


\section{Indikasi Terapi Triangle}

1. Masalah dengan pasangan

2. Perceraian atau putus hubungan dengan pasangan

3. Pasangan dengan perilaku kekerasan

4. Post traumatic stres disorder

5. Masalah perilaku pada anak

6. Masalah yang melibatkan keluarga besar

\section{Proses Pelaksanaan Terapi Triangle}

Penting untuk dipahami bahwa sebelum melaksanakan terapi yang harus dilaksanakan oleh terapis adalah mengidentifikasi keluarga yang memiliki masalah. Setelah itu keluarga diberi penjelasan tentang terapi ini, dan jika keluarga setuju buat kontrak dengan Terapis yang meliputi pertemuan selama 6 sesi. Kemudian Terapis mengidentifikasi masalah klien dan keluarga secara terpisah,hal ini dilakukan untuk mendapatkan persepsi yang sama. Setelah ditemukan kesamaan dalam masalah yang dihadapi maka klien dan keluarga dapat dipertemukan dalam terapi.

Sesi 1: Identifikasi masalah,dengan tujuan klien dan keluarga dapat mengungkapkan persaan,menjelaskan masalah yang dihadapi keluarga dan memilih prioritas masalah yang akan diatasi. Pada sesi ini Terapis harus mengidentifikasi dimana Triangle dan siapa saja yang terlibat.

Sesi 2: Identifikasi kompetensi,dengan tujuan klien dan keluarga dapat menjelaskan peran dan keluarga, fungsi dalam keluarga, dan cara berkomunikasi yang dilakukan dalam keluarga.

Sesi 3: Kolaborasi, dengan tujuan klien dan keluarga dapat menjelaskan rencana pemecahan masalah,sumber-sumber pendukung yang terlibat selama ini,dan harapan yang ingin dicapai terapi.

Sesi 4: Penyelesaian masalah(sistem dan struktur keluarga) dengan tujuan klien dan keluarga dapat menyampaikan cara mengatasi masalah yang dipilih dan telah dilakukan,siapa saja yang membantu mengatasi masalah,dan siapa saja yang membuat keputusan dalam keluarga.

Sesi 5: Penyelesaian masalah (hubungan dan cara merawat) dengan tujuan klien dan keluarga dapat menjelaskan hambatan-hambatan dalam menyelesaikan masalah,cara yang sudah dilakukan untuk menangani hambatan, dan dukungan yang diberikan oleh keluarga serta cara melakukan perawatan terhadap klien selama ini.

Sesi 6: Evaluasi hasil,dengan tujuan klien dan keluarga dapat memamfaatkan kemampuan diri, sistem pendukung keluarga dan sistem rujukan pelayanan kesehatan yang ada. 


\section{BAB 3}

\section{PEMBAHASAN}

\section{Analisis terapi yang dipilih untuk untuk menyelasaikan masalah koping keluarga tidak fektif}

Koping keluarga tidak efektif adalah suatu keadaan keluarga yang menunjukkan resiko tinggi perilaku dekstruktif dalam berespon terhadap ketidakmampuan untuk mengatasi stresor internal atau eksternal karena ketidakmampuan (fisik,psikologis,dan kognitif) yang dimiliki (Keliat dkk,2011). Makanya perlu untuk memberikan dukungan secara moril terhadap keluarga yang kopingnya tidak efektif, dengan keadaan ini pemberian terapi keluarga seperti: terapi keluarga psikoedukasi,terapi triangle dan terapi kelompok seperti: terapi supportif sangatlah penting. Dalam pembahasan ini akan dipaparkan mengapa perlu diberikan terapi spesialis keperawatan ini terhadap keluarga yang kopingnya tidak efektif.

\subsection{Terapi Supportif}

Terapi suportif merupakan bentuk terapi kelompok yang dipandu oleh seorang tenaga profesional yang membantu anggota kelompok untuk dapat beradaptasi dan mengatasi masalah yang dihadapinya melalui dukungan dari dalam kelompok terapi (AGPA, 2007). terapi suportif terdiri tiga prinsip dasar, yaitu ekspresi perasaan, dukungan sosial dan keterampilan manajemen kognitif. Dukungan sosial dan ekspresi perasaan memberikan dorongan emosi yang kuat bagi anggota kelompok dan mengembangkan sumber pendukung yang baru bagi mereka (Spiegel, 2000 dalam Shectman, 2002).

Rockland (1989 dalam Stuart dan Larai, 2005) menyatakan bahwa terapi suportif efektif untuk mengatasi masalah ansietas, stres post trauma, gangguan makan, penyalahgunaan zat, serta beberapa penyakit fisik. Terapi suportif juga dapat digunakan untuk mengatasi kesulitan dalam melakukan hubungan interpersonal (perasaan isolasi, depresi, ansietas), masalah yang dihadapi anak dan remaja (perceraian, kelompok teman sebaya, masalah belajar, atau perilaku), penuaan, dan penyakit medis (AGPA, 2007).

Peristiwa yang dialami sepanjang siklus kehidupan merupakan sumber stressor yang positif maupun yang negatif. Stressor inilah yang membuat seseorang menggunakan mekanisme koping, apabila individu dapat beradaptasi dengan baik terhadap masalah yang dihadapi maka individu tersebut sudah mampu menggunakan mekanisme koping dengan baik tetapi kebalikannya apabila tidak mampu beradaptasi dengan baik mekanisme kopingnya menjadi tidak efektif. Akibat mekanisme koping yang tidak efektif dapat menimbulkan berbagai masalah ansietas, isolasi, depresi dan masalah lainnya. 
Tujuan dari pelaksanaan terapi suportif adalah memberikan support, fokus untuk pemulihan, aksi sosial termasuk kebijakan organisasi. Tujuan dan harapan dalam group adalah pengalaman kelompok yang positif, resolusi permasalahan dengan segera, memberikan motivasi dan perubahan perilaku individu. Dalam pelaksanaan terapi suportif anggota kelompok dapat menceritakan pengalamannya, respon terhadap peristiwa yang dialami serta masalah-masalah yang dihadapi. Melalui ekspresi perasaan anggota kelompok merasa bukan hanya satu orang saja yang memiliki masalah tetapi semua anggota kelompok juga mempunyai masalah masing-masing.

Berdasarkan penelitian yang telah dilakukan Swasti (2011) pada siswa kelas XII SMAN 1 Kuta Sari didapatkan bahwa terapi suportif berpengaruh terhadap penurunan ansietas siswa dalam menghadapi ujian nasional. Hal ini sejalan dengan penelitian yang dilakukan oleh Hernawati pada keluarga yang memiliki anggota keluarga dengan gangguan jiwa menunjukkan peningkatan kemampuan kognitif, afektif dan psikomotor keluarga dalam merawat klien gangguan jiwa secara bermakna pada kelompok keluarga yang mendapatkan terapi suportif keluarga. Kemampuan keluarga yang mendapat terapi suportif keluarga meningkat lebih tinggi secara bermakna dibandingkan kelompok keluarga yang tidak mendapatkan terapi.. Maka dengan penelitian yang telah dilakukan oleh Hermawati bahwa terapi ini bisa dilakukan pada keluarga yang membutuhkan terapi kognitif,afektif dan psikomotor sehingga akoping keluarga menjadi efektif.

\subsection{Terapi Psikoedukasi Keluarga}

Beberapa kemampuan dan efektifitas terapi kelurga secara mendalam memberikan kepercayaan diri tentang bagaimana kekuatan keluarga untuk meningkatkan nilai-nilai kooperatif dan timbal balik, mengurangi kekuatan peranan, dan konstruk dalam maneuver sebuah tindakan tingkah laku. Keluarga dalam situasi krisis secara terpisah mudah untuk keluar dari struktur, khususnya dalam pola garis besar antara masing-masing generasi dan anggota keluarga. Masing-masing keluarga memiliki respon yang tinggi untuk menyusun kembali teknik-teknik "restructuring" garis besar kekuatan antara anggota dan perbedaan sub sistem. Pembentukan garis-garis besar fungsi yang lebih baik secara umum merupakan hasil dalam perkembangan kooperatif dan efektifitas pemecahan masalah yang didasari pada kemunculan angota keluarga yang komponennya berbeda dalam sistem keluarga makanya perlu diberi terapi keluarga agar keluarga dapat menerima anggota keluarga satu sama lain dan bisa lepas dari situasi krisis itu.

Menurut Carson (2000),Psikoedukasi merupakan alat terapi keluarga yang makin populer sebagai suatu strategi untuk menurunkan faktor-faktor resiko yang berhubungan dengan perkembangan gejala-gejala perilaku. Jadi pada prinsipnya psikoedukasi dapat membantu anggota keluarga dalam meningkatkan pengetahuan tentang penyakit melalui pemberian 
informasi dan edukasi yang dapat mendukung pengobatan dan rehabilitasi pasien dan meningkatkan dukungan bagi anggota keluarga itu sendiri. Dengan pemberian terapi psikoedukasi pada keluarga diharapkan dapat membantu keluarga dalam meningkatkan pengetahuan tentang penyakit yang dialami oleh anggota keluarga dengan cara memberikan informasi pada keluarga.

Berdasarkan penelitian yang dilakukan oleh Nurbaini,(2009) pada keluarga yang merawat pasien stroke di RSUPN Dr.Cipto Mangunkusumo Jakarta,didapatkan bahwa psikoedukasi keluarga terhadap masalah psikososial ansietas dan beban keluarga yang diberikan sangat berpengaruh dan hal ini juga sejalan dengan penelitian yang dilakukan oleh Sari.H.,(2009) bahwa Family Psychoeducation Therapy terhadap beban dan kemampuan keluarga dalam merawat klien pasung di kabupaten Bireuen Nanggroe Aceh Darussalam sangat berpengaruh besar, karena hasil uji statistik munjukkan penurunan beban keluarga dan peningkatan kemampuan keluarga secara bermakna setelah mendapat Terapi psikoedukasi. Dan penelitian yang berhubungan dengan masalah fisik yang menimbulkan masalah psikososial dilakukan oleh Boesen,dkk,(1993) menujukkan hasil berkurangnya kelelahan,bersemangat atau tenaga lebih kuat,gangguan suasana hati lebih rendah dibanding dengan kelompok kontrol.

\subsection{Terapi Triangle}

Didalam terapi keluarga, keluarga dipandang sebagai sistem yang anggotanya saling bergantung satu sama lain, perubahan yang terjadi pada satu anggota keluarga didalamnya akan mempengaruhi atau menciptakan perubahan kepada anggota yang lain. Maka dengan berjalannya waktu ditemukanlah Terapi Triangle yang dapat memberikan perubahan pada keluarga yang lebih baik dengan memberikan terapi ini kepada keluarga yang membutuhkan dukungan sosial karena terapi triangle ini mengacu pada konfigurasi emosional tiga orang yang dianggap merupakan bagian dasar dari sistem keluarga dimana tujuannya untuk membantu pasangan dan individu mengantisipasi berbagai cara dalam menyelesaikan masalah-masalah yang timbul

Menurut Kazak,Simms \& Rourke (2002) mamfaat dari terapi Triangle adalah :

1. Orientasi berfokus pada keluarga bukan pada individu

2. Fokus pada pemahaman keluarga terhadap struktur keluarga,peran,fungsi ,sosial dan budaya yang akan mempengaruhi stabilitas hubungan keluarga

3. Menjelaskan timbal balik hubungan keluarga sebagai tolak ukur keberhasilan

4. Membantu keluarga yang mempunyai masalah.

Maka dengan pernyataan yang dijelaskan diatas dengan perkembangan dunia keperawatan yang sangat pesat maka perawat spesialis telah meneliti keabsahan pernyatan itu bahwa terapi triangle sangatlah perlu dilaksanakan didalam kelurga. Dalam penelitian yang dilakukan oleh Widiastuti, (2007) tentang" Pengaruh terapi keluarga triangle terhadap kemampuan keluarga dalam merawat anggota keluarga yang mengalami ganggua jiwa di RSJ Bandung" terbukti bahwa terapi triangle sangat memberikan pengaruh yang bermakna bagi keluarga. Maka terapi triangle ini cocok diberikan pada keluarga yang anggota 
keluarganya mengalami gangguan jiwa dan penyakit kronis lainnya supanya keluarga dapat menerima keadaan dan memberikan perawatan pada anggota keluarganya.

\subsection{Usulan Terapi Yang Tepat Untuk Koping Keluarga Tidak Efektif}

Terapi adalah usaha yang dilakukan untuk menyembuhkan dan memulihkan kesehatan orang yang sakit. Penyembuhan dan pemulihan ini harus didukung oleh keluarga sesuai dengan perkembangan ilmu pengetahuan di dunia kesehatan maka terciptalah terapi keluarga dimana terapi keluarga akan melibatkan klien dan keluarga dalam penyembuhan anggota keluarga yang mengalami masalah kesehatan maupun masalah psikologis. Terapi keluarga adalah salah satu jenis terapi modalitas yang berfokus pada pengobatan seluruh anggota keluarga sebagai unit dan bentuk intervensi yang diberikan adalah membantu keluarga untuk mengidentifikasi dan mengubah masalah yang maladaptif, menyalahkan diri sendiri, dan hubungan pola yang berulang (Goldenberg \& Goldenberg dalam Townsend, 2005).

Berdasarkan penjelasan diatas bahwa di dalam sebuah keluarga harus mampu mengidentifikasi masing-masing anggota keluarga sehingga keluarga dapat mengetahui masalah dari setiap anggota keluarga anggota. Apabila didalam sebuah keluarga ada anggota keluarga yang mengalami masalah yang berat atau kronis itulah yang membuat koping keluarga tidak efektif akibat kecemasan dan stresor yang dialaminya. Disinilah kita fungsikan terapi keluarga itu untuk membantu keluarga supanya kopingnya bisa efektif dan mau merawat anggota keluarganya dan bisa keluar dari masalah yang berat itu. Dengan beberapa terapi yang dipaparkan diatas maka yang paling sesuai diberikan kepada keluarga yang mengalami koping yang tidak fektif adalah semua terapi yang telah dibahas diatas tergantung kesesuaian dan kebutuhan keluarga atau sesuai dengan masalah yang dihadapi karena dilihat dari tujuan dari semua terapi adalah dengan tujuan meningkatkan pengetahuan keluarga dengan cara memberikan informasi untuk membantu keluarga dalam mengahadapi masalah yang ada di dalam keluarga.

Penulis mengusulkan bahwa terapi yang paling sesuai dari yang dipaparkan diatas adalah Terapi Psikoedukasi Keluarga, karena terapi ini dapat memberikan support langsung kepada keluarga yang kopingnya tidak efektif jadi tidak membebani klien untuk ikut dalam terapi ini sehingga keluarga langsung dapat mengekspresikan beban yang dirasakan kepada Terapis tentang masalah keuangan,sosial,dan psikologis dalam memberikan perawatan yang lama untuk anggota keluarganya. Terbukti dengan pembahasan dari beberapa penelitian diatas yang berhubungan dengan masalah fisik dan mental anggota keluarga yang menimbulkan masalah psikososial keluarga (koping keluarga tidak efektif) munjukkan penurunan beban keluarga dan peningkatan kemampuan keluarga secara bermakna setelah mendapat terapi psikoedukasi. 


\section{DAFTAR PUSTAKA}

1. Friedman (1998). Keperawatan Keluarga. Jakarta: EGC

2. Kazak, A. E., Simms, S., \& Rourke, M. T. (2002). Family systems practice in pediatric psychology. Journal of pediatric psychology, 27(2), 133-143.

3. Pardede, J. A. (2020). Terapi Keluarga. Jurnal Kesehatan 10 (3)

4. Friedman, M. (2010). Buku Ajar Keperawatan keluarga: Riset, Teori, dan Praktek. Edisi ke-5. Jakarta: EGC

5. Nies, M., \& Mc Ewen, M. (2001). Promoting the health of Populations. Community health nursing.

6. Pardede, J. A. (2021). Standar Asuhan Keperawatan Dengan Kesiapan Peningkatan Pengetahuan. Jurnal Keperawatan

7. Keliat, B.A. \& Akemat, Susanti, H. (2011). Manajemen Kasus Gangguan Jiwa CMHN (Intermediate Course). Jakarta: EGC

8. Keliat, Dkk. (2013). Ilmu Keperawatan Jiwa Komunitas. Jakarta: EGC

9. Yosep, I. (2009). Keperawatan jiwa edisi revisi. Bandung: PT.Refika Aditama.

10. Stuart, G.W \& Laraia (2005). Principle and practice of psyhiatric nursing. St.Louis : Mosby Year B

11. NANDA. (2008), Nursing Diagnoses : Definition \& Classification, Philadelphia : AR

12. Pardede, J. A. (2018). Pelaksanaan Tugas Keluarga Dengan Frekuensi Kekambuhan Pasien Skizofrenia Dengan Masalah Isolasi Sosial. Jurnal Keperawatan Jiwa, 6(2)

13. Workshop Keperawatan Jiwa FIK-UI, (2014). Kumpulan Terapi Individu, Jakarta: FIKUI (Tidak dipublikasikan) 


